\title{
An Assessment of the Educational Choices of Emerging Adults from a Small Mennonite Denomination and their Later Church and Service Involvement
}

Daniel A. Ziegler

Nova Southeastern University

\begin{abstract}
This study was designed to provide Rosedale Bible College, a Conservative Mennonite Conference school in Ohio, with critical information to increase its understanding of the educational choices of emerging adults from its sponsoring denomination and the way those choices correlate with church involvement and volunteerism later in life. The study also offers a glimpse into the educational and religious context of these young adults and the denomination they were part of as youth. A 16-question survey was distributed to 1,068 individuals ages 26-32 who attended one of the denomination's churches when in high school. The survey queried respondents on personal data, educational choices, church involvement, and volunteerism. A total of 240 valid surveys were received, including 47 respondents who had attended the denomination's college. Through cross tabulation and testing for statistical significance, the research found that attendance at the denomination's college was moderately related to greater regular church attendance compared to those who did not attend the college. In addition, attendance at the college was moderately related to a lower likelihood of regular civic volunteerism. Research also found a strong relationship between a secular education and a lower likelihood of regular church attendance later in life, compared to those who participated in formal religious educational experiences as young people.
\end{abstract}

\section{Key Words}

Religious education; Curriculum development; Biblical studies; Higher education; Conservative Mennonite Conference; Emerging adulthood; Religiosity; Service learning; Church attendance 


\section{Introduction and Statement of Problem}

\section{Topic and Background}

Ultimately, the effectiveness of an institution will be measured against its stated mission; in other words, an institution must answer the question whether or not it is achieving what it says it exists to achieve. In higher education, mission-centric outcomes assessment has become a central objective among United States educational accrediting bodies (Ewell 2008; U.S. Department of Education 2006). In response to this growing expectation, this study was developed to provide a denominationally owned Mennonite Bible college with critical information designed to contribute to an understanding of its effectiveness in a core tenet of its mission.

The subject institution, Rosedale Bible College, is a two-year college affiliated with the Conservative Mennonite Conference and located in central Ohio. The vast majority of the school's regular financial support comes from individuals and congregations within this group, and a majority of the school's students come from affiliated churches (Ziegler 2011). Most of the members of the college's board of trustees are members of this denomination as well.

The college's stated mission is, “To provide an evangelical junior Bible college education in the Anabaptist / Mennonite tradition, equipping students to grow spiritually and academically and to serve effectively in the church and in society” (Rosedale Bible College [RBC] 2011, 6). This mission statement, which has existed in its current iteration since 1997, expresses the school's reason for existence and guides the college's strategic planning. However, the college does not have sufficient empirical data regarding the extent to which its current curriculum contributes to its mission of equipping students for service in the church and in society.

\section{The Research Problem}

For purposes of assessment, the college's mission statement can be broken up into three segments. The first portion, "to provide an evangelical junior Bible college education in the Anabaptist / Mennonite tradition” (RBC 2011, 6) is functionally self-evident. The college's evangelical and Anabaptist / Mennonite theological credentials can easily be measured by its formal church affiliation, its espoused statement of theology, the content of its biblical study courses, as well as the denominational affiliation of its board, faculty, and staff members. The school's status as a "junior Bible college" (6) is also easily verifiable by its curriculum, its degree offerings, its relationship with its accreditor, and its degree granting authorization from its state's board of regents.

The second portion of the mission statement addresses "equipping students to grow spiritually and academically" (RBC 2011, 6). Institutional effectiveness in this area can be readily measured by evaluating student's knowledge, beliefs, and attitudes before, during, and after their time at the college. In fact, educational outcomes comprise the bulk of the college's 
self-assessment activities at this time.

Measuring outcomes related to the last part of the mission statement, which addresses “equipping students for service in the church and in society” (RBC 2011, 6), has proven to be a significant assessment challenge for the college. While the college can readily measure initiatives aimed at preparation for church and community service within its current curriculum and prescribed student experiences, the institution is deficient in empirical evidence to help it analyze long-term patterns of church and community service involvement in the lives of former students.

There have been two primary challenges that have hindered college leaders in their assessment of long-term patterns of church and community service involvement among alumni. First is the formative and ephemeral nature of young adulthood. Recent research has shown that most people within western society now experience an extended period of transience during their 20s before they become established in more consistent patterns of adult behavior, such as church attendance and civic volunteerism (Arnett 2000; Barna 2006; Uecker, Regnerus, and Vaaler 2007). The fact that the college in this study is a two-year institution, with primarily 18- to 21year-olds in attendance, means that many of its students are not likely to make long-term church affiliation and service commitments at this point in life, or even during the first number of years following graduation.

A second complication is that patterns of religiosity and volunteerism are best understood when compared to the larger population from which the alumni have come. Currently there is little information available to the college concerning the church attendance and service patterns of those originally from the sponsoring denomination whether or not they have chosen to attend this particular college. This study was designed to help address this deficiency.

\section{Literature Review}

\section{Historical, Religious, and Educational Background}

The small Mennonite denomination and its Bible College that are the locus of this article emerged from a fairly distinct set of religious and historical circumstances. This context includes the ethos of commitment to service that has emerged in this institution.

Mennonites, Bible schools, and religious training

Mennonites are a nearly 500-year-old Christian group. Today, Mennonites range from the Old Order Mennonites, who dress “plainly” and use only horses and buggies for transportation, to the culturally mainstream and more theologically liberal Mennonite Church USA, which is the largest body of Mennonites in America with over 100,000 members (Kraybill 2010, 257). The Conservative Mennonite Conference (CMC), which is the sponsoring denomination of the college in this study, is theologically more conservative than the Mennonite Church USA, yet more mainstream in practice than the "plain” Mennonite churches. This church group currently 
has 107 congregations representing roughly 15,000 attendees (CMC 2011, 53).

The CMC began in 1910 as a number of like-minded Amish congregations united around a more evangelistic agenda than traditional Amish groups would allow, while at the same time striving to maintain a stronger separation from the world than their more assimilated AmishMennonite brethren were practicing (Yoder 2014, 39). Up until the late twentieth century, many CMC churches maintained a degree of visible nonconformity and could be considered "plain" according to the symbolic distinctives outlined by Anderson (2013, 36). By century’s turn, however, "few visible markers separated them, and ministers had little will to enforce uniform ways of dressing and behaving” (Yoder 2014, 22). The group presently considers itself “evangelical-Anabaptist” in theological orientation (Yoder 2014, 392).

Rosedale Bible College began as a six-week winter Bible school through an action of the CMC's annual ministers' meeting in the summer of 1951 when a newly constituted school board was commissioned (Yoder and Showalter 1992). This board, at its first meeting in September 1951, prioritized the school's focus in support of the mission of conference churches with the following purpose statement: "To provide a conference sponsored opportunity for intensive Bible study for our people” (15). The college was one of dozens of short-term Bible schools begun by Mennonite church groups in North America, mostly in the first half of the 20th century (Lederach and Bender 1959).

Historically, among Protestant movements, Mennonites have been known for their commitment to the separation of church and state, a refusal to bear arms, a simple and nonconformed lifestyle, and a conviction that the Christian life should be expressed in active service to others (Wenger 1977). These values have typically been in evidence within the curriculum and programs of Mennonite Bible schools.

The short-term Mennonite Bible schools that developed were, to a large degree, winter programs intended to serve the mostly rural populations of Mennonites who, at the time, generally did not go to high school or college (Yoder and Showalter 1992). The seasonal nature of agrarian and trade-related employment among many Mennonites facilitated extended periods away from home for young people during the winter months. The teaching emphasis of these schools represented a specialized and focused effort to "advance Bible literacy and doctrinal soundness” among the congregants of the sponsoring groups of Mennonites (4).

As educational and career patterns within the Mennonite population broadened in the latter half of the 20th century, the programs of many of these Mennonite Bible schools became anachronistic and most of them were discontinued. An exception would be a small number of winter Mennonite Bible schools that continue to be affiliated with more traditional/ plain Mennonite groups.

Among the non-plain Mennonite communities, however, the few Bible schools that endured did so by lengthening their school year, and by eventually evolving into accredited 
institutions of higher learning (Gingerich 1953). Yet, while all of the other eight accredited Mennonite colleges in the United States are liberal arts institutions, the college in this study has uniquely become an accredited Bible college. As such, it has focused its mission on equipping students spiritually and academically "for service in the church and in society" (RBC 2011, 6). This mission is reflective of both the Mennonite focus on lives of active service, and the Bible college ethos of preparation for Christian ministry.

\section{Bible College and service}

The Mennonite Bible schools that began in the first half of the 20th century were part of a broader movement within theologically conservative evangelical Christianity in the United States that saw the creation of roughly 200 Bible colleges and institutes between 1880 and 1960 (McKinney 1997). Most of these institutions were begun "as a protest to the inroads of secularization in higher education and as a base for the education of lay-workers and full-time Bible teachers, evangelists, and pastors” (65).

The characteristic of commitment to service indicative of the Mennonite faith is also shared as a core value within the contemporary Bible college movement. In his history of the movement, McKinney (1997) asserted the importance of the continuing primacy of this service ethos by observing:

There must be an affirmation to equip students for service in the church and society. This is the primary reason why the Bible college movement was called into existence. Bible colleges have provided trained workers, professionals and laity, for over 100 years. Their alumni are a major force within North American ministries and parachurch ministries around the world. (209)

Service experiences and preparation for vocational Christian service continue to be central to the Bible college movement.

\section{Emerging Adulthood and Religious Beliefs}

Today, the vast majority of the students served by the Bible College that is the focus of study are "traditional" college students, meaning they are full-time young adult students. According to Arnett (2000), the 18-25 age group, which he called emerging adulthood, now represents "a distinct period demographically, subjectively, and in terms of identity explorations" (471). Arnett observed that delayed marriage, now averaging in the mid to upper 20s in western societies, and an increasing number of young adults pursuing education well beyond their high school years, has created a time "of frequent change as various possibilities in love, work, and worldviews are explored” (469).

Embedded within the emerging adult quest for identity and worldview is often a time of spiritual questioning and development of religious beliefs and faith-based commitments (Barry, 
et al. 2010). For many emerging adults, this is manifest in a period when they become disaffiliated with the faith tradition in which they were raised. In fact, research has indicated that $30 \%$ to $40 \%$ of young adults previously involved in organized religion become disengaged, at least temporarily, from formal religious involvement during the emerging adult years (Barna 2006; Uecker, Regnerus, and Vaaler 2007).

This developmental journey, particularly as it relates to individual faith, has been effectively cataloged in one of the most significant studies ever undertaken of the religious development of adolescents and emerging adults, the National Study of Youth and Religion (NSYR). This extensive study began in the summer of 2002 and has continued longitudinally to produce a wealth of information regarding beliefs, attitudes, and religious development among youth and emerging adults (Smith and Denton 2005).

The NSYR revealed that, contrary to popular perceptions, most young people in America are not spiritual seekers to any significant degree. Smith and Denton (2005) asserted: "The vast majority of American adolescents are not spiritual seekers or questers of the type often described by journalists and some scholars, but are instead mostly oriented toward and engaged in conventional religious traditions and communities" (27). This theme was echoed in the research of Barna (2001), whose examination of the attitudes of over 1,200 teenagers (who are now emerging adults) concluded that, "most teens are highly interested in spirituality, but comparatively few are engaged in the pursuit of spiritual depth" (61).

\section{Patterns of Religious Attendance and Volunteerism}

\section{Attendance at religious services}

According to recent surveys, slightly over $40 \%$ of Americans report attending religious services in any given week (Princeton Religious Research Center 2002). However, other research seems to show that this self-reported number is likely too high, mainly because people, particularly those who strongly identify with a religious tradition, tend to over-report their church attendance (Brenner 2011). Sociologists call this propensity to inflate self-reported behavior social desirability bias. Research using alternate measures that focus more on actual or sampled congregational head counts has found that regular church attendance is more likely $20 \%$ to $22 \%$ (Hadaway and Marler 2005; Hadaway, Marler, and Chavez 1998).

One of the largest and longest-running social surveys in America is the General Social Survey (GSS). This survey, which has been consistently gathering data on American society for four decades, showed that weekly church attendance was 31\% for the general population during the decade of 2000 to 2010 (Smith, et al. 2012). While this number is also a self-reported number, the over-reporting effect may be tempered some because of the face-to-face data collection method the GSS uses.

When broken down by age, attendance at religious services seems to reach its nadir 
during the emerging adult years in most studies. A recent Pew Research Center (2010) study of millennials, which is the Pew Center's name for the generational cohort born after 1981 who came of age at the turn of the millennium, found self-reported religious service attendance of nearly every week or greater among those aged 18-29 was 33\%, the lowest of any of the age groups in the Pew study.

The NYSR found that weekly attendance among emerging adults was much lower at just over 20\% (Smith and Snell 2009). The GSS concurred. According to the GSS statistics for 2000 to 2010 (Smith, et al. 2012), attendance at religious services once a week or more for emerging adults is only $20 \%$. However, after the decline from adolescence into emerging adulthood, religious attendance tends to increase over time. For 30-year-olds, the GSS found that regular attendance rose to slightly over $25 \%$, and this percentage continued to go up until it peaked at just over $40 \%$ for individuals in their 60 s.

The evangelical Christian subset is the religious grouping from the GSS that likely best approximates the cultural and religious context of the Mennonites in this study. According to the GSS, nearly 37\% of evangelical emerging adults from the 2000 to 2010 data set report regularly attending religious services. This percentage is quite a bit higher than reported by their nonevangelical peers (Smith, et al. 2012). The Pew Research Center (2012) found the percentage of self-reported weekly attendance at religious services was $55 \%$ for 18 - to 29 -year-olds who claimed affiliation with evangelical churches.

\section{Volunteerism}

According to the U. S. Bureau of Labor Statistics (2008), just over 25\% of Americans ages 16 or above volunteer in a given year. Research that relies on self-reporting indicates a significantly higher number, with $47 \%$ of Americans reporting that they volunteer for civic or non-church service organizations at least once in a given year (Greely 1997, 68). This difference in percentage between these two sources may again be due to over-reporting related to the social desirability bias.

Many adults report volunteering more regularly as they age, according to data from the GSS. Among 18-year-olds, self-reported volunteerism for charitable or civic organizations in a given year is below $20 \%$, but rises to $37 \%$ by age 30 , and peaks near $50 \%$ for individuals in their mid-40s (Smith, et al. 2012). The Pew Research Center's (2010) study of millennials ages 18- to 29-years-old found that 57\% reported volunteering at least once in the past 12 months, which was again a bit higher than reported in other surveys.

As the NSYR entered its third wave, which was launched five years after its initial study, it examined the lives and beliefs of the same original survey respondents who had now entered emerging adulthood (Smith and Snell 2009). The survey found that, on average, $40 \%$ of emerging adults reported volunteering for a community organization at least once in a given year, with $12 \%$ volunteering monthly or more (262). These volunteerism numbers for emerging adults 
are below the self-reported norms for adult Americans. As was the case with church attendance, emerging adults report a significant drop in volunteerism from those reported during adolescence (Gibson 2008).

As the NSYR authors considered the overall commitment to religious involvement and volunteerism among emerging adults, particularly in light of the extensive interviews conducted as a part of the survey, Smith and Snell (2009) made the following observation:

Emerging adults are not only less religiously committed and involved than older adults, but also tend to be less involved in and committed toward a wide variety of other, nonreligious social institutional connections, associations, and activities. Emerging adults, for instance, belong to fewer voluntary associations, give less money in charitable donations, volunteer less, and read newspapers less than older adults. (92)

The authors asserted that emerging adults "reflect only slight awareness that they may now, even in small ways, be establishing patterns and priorities concerning time and money that will carry through the rest of their lives” (71).

\section{Religiosity, Education, and Service}

It is well established within social research that religiosity is positively related to civicminded behaviors such as volunteering and charitable giving (Brooks 2006). In fact, the difference between volunteerism among religiously engaged individuals and those not involved in organized religion can be striking. One study found that over 50\% of Americans who attend religious services nearly every week or more are also engaged in volunteerism, while only 19\% of non-churchgoers volunteer (Musick and Wilson 2008, 279).

This relationship between religious attendance and volunteerism has also been observed among adolescents (Gibson 2008) and among emerging adults (Ozorak 2003). For example, the emerging adults whom the NYSR identified as religiously “devoted” were three times more likely to volunteer for community service on a regular basis than the emerging adults who were identified as religiously "disengaged” (Smith and Snell 2009). Smith and Snell posited that adolescents might be affected by an intrinsic motivation to "live out their faith and please God in ways that those disengaged from religion do not share” (262).

The commitment to volunteerism seems to be impacted by an individual's level of educational attainment as well. According to Musick and Wilson (2008), education is "the most consistent, and often strongest, predictor of volunteering” (119). For example, government data show that among adults 25 years old or greater, those with a bachelor's degree or higher are nearly five times as likely to volunteer as are those with less than a high school diploma (U.S. Bureau of Labor Statistics 2008). 


\section{The age effect}

One of the questions facing those who are studying this particular generation of emerging adults is whether these established patterns of religious and civic disengagement are more or less permanent fixtures for this cohort.

History tells us that, at least in part, this is a likely occurrence. If emerging adults follow the patterns of those who have preceded them, over time they are likely to increase their volunteerism and religious service attendance (Smith, et al. 2012). This pattern of predictable and often temporary behaviors at various stages of life is referred to by social scientists as the age effect (Smith, et al. 2011, 214).

Much of the research examining this current group of emerging adults points to the possibility that their disengagement from formal religious and service involvement may be a temporary condition. For example, this pattern was highlighted in a longitudinal study that interviewed 38-year-old adults who had previously been interviewed at age 16 . In this study, $79 \%$ of the 206 respondents indicated that they had at some time become inactive in church, mostly during their late teens or early twenties. Interviews found that $58 \%$ of this inactive group had returned to active religious involvement at a later time, with most (62\%) becoming active again between the ages of 23 and 30 (O’Connor, Hoge, and Alexander 2002, 726-727).

However, a number of leading social researchers are concerned that many of these patterns of disengagement may become a fixed construct for this current emerging adult cohort. Smith, et al. (2011, 214) believe that many of the patterns transpiring in the emerging adult years will transcend the age effect. One reason for this is the growing longevity of the emerging adult stage of life, and the extended period during which young people are forming habits and life patterns:

If emerging adults do not begin to learn the practices of public giving and participation early enough, at least by the time they are settling down, we do not have any good reason to believe they will learn them any better later (214).

Kinnaman and Lyons (2007), in their meta-analysis of recent studies of adolescents and emerging adults, came to a similar conclusion, asserting that "those who think that in due time emerging adults will 'grow up' and look like everyone else, should prepare to have unfulfilled expectations" (22).

\section{Faith Development and Education}

\section{Faith development in college}

Higher education and the college setting certainly have an impact on the faith development of emerging adults. The question is, what kind of impact? Does the college experience help or hinder faith development? Of course, there is not one answer to these 
questions that fits all circumstances, and current research offers mixed results.

Some research indicates that religious involvement may be negatively related to educational attainment, especially over the short-run during a student's college career. For example, one study that followed students over three semesters found that, "in the aggregate, significant declines in the behavioral aspects of religiosity were observed across semesters" (Stoppa and Lefkowitz 2010, 23). This departure from religious involvement among college students may be particularly acute at public colleges and universities, where programs of faith and spiritual development are often formally avoided (Speck 2005).

One major study of religious involvement and expressed beliefs among evangelical Christian students who were active in their faith upon entry into college found that, by the end of four years at non-religiously affiliated colleges, nearly 52\% of them had either renounced their faith or stopped attending religious services regularly. The results for students who attended evangelical Christian colleges were quite different, with $84 \%$ of those students indicating a strengthening of their faith commitment during their time at a Christian college (Henderson 2003).

It is worth noting, however, that the environment for religious development on secular college campuses might be shifting. While earlier research fed the notion that higher education resulted in the secularization of the minds of students (Funk and Wilits 1987; Hadaway and Roof 1988; Hunter 1983), more recent research has recognized that the formerly negative relationship between a secular college education and faith development may be changing.

In their meta-analysis of all the published longitudinal studies of religiosity among college students conducted in the United States since the 1990's, Pascarella and Terenzini (2005) found convincing evidence that students' religious convictions generally increase during college. Another recent study concluded that religiosity among emerging adults does not decrease with educational attainment (Arnett and Jensen 2002). Lee (2002), in a longitudinal study that followed freshmen through four years of college, found that more than $86 \%$ of them reported their religious convictions and beliefs either had increased or remained the same through the

period. Finally, another large study concluded that "contrary to expectations, emerging adults who avoid college exhibit the most extensive patterns of religious decline, undermining conventional wisdom about the secularizing effect of higher education” (Uecker, et al. 2007, 1667).

\section{Religiosity, Volunteerism, and Religious Education}

As has been shown, there is a well-established relationship between education and volunteerism (Brooks 2006; Musick and Wilson 2008). However, there appears to be far less recent empirical study examining the relationship between the particular types of educational experiences a person has during emerging adulthood, and how these choices might correlate with later religiosity or volunteerism. 
Most of the research that does exist seems to point to a moderately positive correlation between primary and secondary religious education and later religiosity. For example, Gunnoe and Moore (2002) found a correlation, linking religious education during early adolescence to religiosity during young adulthood. Additionally, a ten-year longitudinal study of over 1,300 Adventist young people found a relationship between attendance at church-related day schools and continued engagement with denominational churches in emerging adulthood (Dudley 1999). The author concluded that "parochial education, especially in the crucial decision-making period of adolescence, is also an important shaper of adulthood” (116).

However, another study raised some questions about the long-term effects of religious day schools in correlating with the religiosity of former students when they are adults. O'Connor et al. (2002), in their research of the religious activity of 38-year-olds who had previously been interviewed at age 16, found very little correlation between the events and circumstances of their subject's lives at the age of 16 and their attendance at religious services at age 38.

Regarding volunteerism, one major study sought to examine the relationship between the type of secondary education a young person had and their later patterns of volunteerism as an emerging adult. Hill and den Dulk (2013) mined the data from wave one and wave three of the NYSR to examine the volunteerism patterns among students from five categories of secondary schooling: public, Catholic, Protestant, private nonreligious, and homeschooled, with significantly different results found across educational contexts. The results from this study led the authors to state, "We can conclude that schooling itself has a real impact on sustaining volunteering” (Hill and den Dulk 2013, 194).

\section{Methodology}

\section{Participants}

Since 1999, the denominational office of the Conservative Mennonite Conference has annually requested from affiliated churches a contact list of high school aged adolescents who regularly attend congregational activities. Requested data for this list includes the name, address, telephone number, email address, parent's first names, and expected year of graduation for each high school aged student. This list of the denomination's high school aged adolescents was determined to be an ideal source for this study's population because it represented the denomination's most complete age-delineated list of attendees available.

This study has been designed to query individuals from the denomination's list whose expected year of high school graduation was 1999 through 2004. These particular graduation years were chosen because these individuals were now older than age 25, and thus they were no longer in the transient emerging adult age range according to Arnett's (2000) widely used definition.

The total number of individuals from the denomination's list of expected high school 
graduates 1999 through 2004, excluding individuals from churches that have left the denomination since 2004, was 1,068, representing 79 congregations. These congregations represented roughly $90 \%$ of the membership of the denomination's churches at the time. Out of the population of 1,068 individuals, 189 (18\%) had attended the denomination's college at some point. It was estimated that the total population in the denomination's graduation cohorts of 1999 through 2004 was about 1,400 individuals.

The gender distribution of the study was 566 males (53\%), 497 females (47\%). Most of the addresses from the list were from small city, town, and rural locations. No data was gathered on the racial and ethnic makeup of the young people, although it can be surmised from the racial and ethnic makeup of the overall denomination that the vast majority of those on the list were individuals of western European ancestry.

\section{Survey Instrument}

The data for this study were gathered via a 16-question mailed survey developed by the researcher based on the GSS. The GSS was chosen as a model for the survey because of its longevity and its wide acceptance within the social science community.

The GSS has been conducted annually since 1972 by the National Opinion Research Center, and has consistently tracked hundreds of social trends in the United States. In fact, aside from the United States census, the GSS is the most frequently analyzed source of information in the social sciences, with over 14,000 citations in academic journals, books, and dissertations alone (General Social Survey, n.d.). In relationship to this article, the GSS was used as the template for survey questions regarding demographics, church attendance, and volunteerism.

This survey instrument also included a few questions not found in the GSS. These supporting questions were rigorously developed and tested to ensure their clarity and their appropriateness. There were four sections to the survey: personal information, education, church involvement, and service involvement. Each section was designed to provide either primary information for the main correlational study, or secondary information that might be helpful in examining extraneous factors that could affect the main correlational relationships (i.e., gender, marital status, children, high school education, educational attainment, or denominational affiliation).

Age was not used in any of the statistical analyses, but was added as a check to ensure that the participant was, in fact, part of the target population of post-emerging adults. Because participants' expected years of graduation were 1999 through 2004, their ages should have ranged primarily from a minimum of 26 years of age (for 17-year-old graduates from 2004) to 32 years of age (for 18-year-old graduates from 1999). Surveys from individuals younger or older than this age range were considered anomalous and outside of the target population being studied, and were excluded from analysis. 


\section{Procedure}

\section{Design}

Survey forms, along with a brief introductory note, a participation letter, and an addressed return envelope affixed with a first class stamp, were sent to the address of each individual included in the list of the denomination's graduates from 1999-2004. To increase the likelihood of survey response, envelopes containing the survey were hand addressed, and a first class stamp was affixed for postage. The words "Important: please forward” were also handprinted on the envelope to encourage the likelihood that the survey would be forwarded in cases where a particular individual no longer lived at the address provided.

When envelopes were returned from the post office as undeliverable, an attempt was made to find the current address for the potential participant, or their parents, by conducting an internet public record search, or by contacting the church the addressee attended when he or she was in high school. When a new address was found, the survey was mailed out a second time. Surveys returned from the post office a second time were considered undeliverable. Completed surveys were accepted for two months following the date of the initial survey mailing.

\section{Data analysis}

Survey results were compiled and entered into the SPSS diagnostic program, with the raw data from survey questions tabulated in numerical and percentage terms. Cross tabulation with statistical analysis was then used to establish the statistical significance of the data relative to each of the research questions.

Because most of the survey questions represented nominal scale and were predominately dichotomous data, the chi-squared test of independence was the primary test used to establish the statistical significance of relationships. This test provides a nonparametric analysis that “identifies whether observed values differ significantly from expected values” (George and Mallery 2006, 96). In the case of the chi-squared test, the expected values being tested were based on the null hypothesis, which posits that the factors or characteristics being tested were independent or not associated. If the factors are shown to be statistically dependent or associated at the conventional $95 \%$ confidence level or higher $(\alpha<=.05)$, then the null hypothesis was rejected and a relationship was statistically established (Fink 2003).

Since the chi-squared test measures independence only, and not association, in cases when statistical significance was found via the chi-squared test, the phi statistic was also used as “a standardized measure of association” (George and Mallery 2006, 107). The phi statistic standardizes the comparison of association on a scale from 0 to 1.0 by measuring "the relationship between the value of nominal level measures of association and the strength of the relationship” (Healy 2010). 
When the phi statistic value was .10 or below $(\phi<.10)$, the association was considered “weak to nonexistent." When phi statistic value was between .10 and .30 ( $\phi=.10$ to .30), the association was considered "moderate." When phi statistic value was equal to or greater than .30 ( $\phi>=.30)$, the association was considered "strong” (319).

\section{Results and Analysis}

\section{Descriptive Statistics}

Of the 1,068 surveys mailed out to the target population, a total of 255 surveys were filled out and returned, resulting in a response rate of 23.9\%. Out of these completed surveys, 15 were excluded because the respondents indicated an age that was outside of the targeted 26- to 32 -year age range. Thus, the final number of surveys used for analysis was $n=240$, which represented $22.5 \%$ of the total number of surveys mailed. There were 55 survey envelopes returned as undeliverable after second attempts to mail them failed, which represented $5.1 \%$ of the total mailed.

The survey responses received in this study were of sufficient volume to provide reasonably high confidence that the study is an accurate and statistically significant representation of the post-emerging adult population being studied. The only known demographic anomaly was that the response rate for females (27.4\%) was higher than the response rate for males (18.4\%). However, since analysis found no statistically significant difference between genders in their responses to the primary behaviors being measured in this study, the researcher concluded that it did not affect survey results substantively.

\section{Education}

The makeup of secondary educational choices within the survey population differed substantially from national norms. According to a recent report from the U. S. Department of Education (2010), 89\% of American students enrolled in high school attend public schools, 7\% attend private religious high schools, and 3\% attend private nonsectarian high schools. In addition, 2.9\% of American high school students are homeschooled.

Among the survey population, the rate attending public high school (45.4\%) was about half the rate for the general population. Furthermore, the percentage attending religious high schools (38.7\%) was significantly higher than the general populace, as was the homeschooled percentage (13.8\%). These preferences among survey respondents likely reflect the historic commitment within this Mennonite community to parochial education (Yoder and Showalter 1992), and a residual socio-religious preference, found within much of Anabaptism, for a degree of separation from the cultural and ideological context of dominant society (Kraybill 2010).

A large majority of survey respondents (82.1\%) attended some type of formal postsecondary schooling, with $66.2 \%$ receiving a certificate or degree. The most common post- 
secondary degree was the bachelor's degree (32.1\%), followed by the associate's degree (15.0\%). A total of $10.4 \%$ earned a graduate or doctoral degree. A variety of college types were represented among the responses, including 47 respondents who attended the Bible College at the center of this study for longer than one 15-week semester (see Table 1).

Overall, the survey population was more highly educated than the general population of the United States. Reported high school graduation rates were in excess of $98 \%$, and college attendance was greater than $82 \%$ for the young people from this Mennonite denomination. In comparison, the high school graduation rate for the American population in 2007 was closer to 81\% (Heckman and LaFontaine 2010) and the college attendance rate was slightly less than 50\% (U.S. Department of Education 2011).

These higher graduation and college rates among the survey population reflect a significant pattern shift for this mostly rural Mennonite denomination's participation in education over the course of the past 50 years. Historically, into the mid-20th century, the mostly rural agrarian Mennonites from the denomination that began the Bible college had not embraced higher education in any significant way (Yoder and Showalter 1992). According to information gathered in 1962 from attendees of the denomination's Bible institute, only 28\% of students had completed high school at that time, and 33\% of students had not attended high school at all (Yoder and Showalter 1992).

\section{Table 1: Types of Formal Post-Secondary Education}

\begin{tabular}{lll} 
Type of Institution & $\mathrm{n}$ & $\%$ \\
\hline Christian College/ Seminary & 69 & 28.7 \\
Community College & 66 & 27.5 \\
State College/ University & 50 & 20.8 \\
Rosedale Bible College & 47 & 19.6 \\
Vocational/ Technical Institute & 18 & 7.5 \\
Private (non-Christian) College & 17 & 7.1 \\
(Non-RBC) Bible College & 8 & 3.3 \\
Other & 1 & 0.4 \\
\hline
\end{tabular}

Note. Respondents could pick more than one educational type. Percentages given are relative to $\mathrm{n}$. Attendance of one semester or less at a particular educational type was excluded. 
A majority of survey respondents (70.0\%) did not participate in formal training experiences in addition to high school and college. The largest group of those who did have extra-collegiate training participated in discipleship training schools (14.2\%) or short-term mission experiences (13.8\%). Discipleship training schools are parachurch programs involved in providing intensive training in missions and spiritual disciplines, generally for young adults.

\section{Church involvement}

In terms of church attendance, the population in this study attended church services with regularity that was significantly higher than the general population in the United States. Over $78 \%$ of those surveyed reported attending church services nearly once a week or more. This compares to regular religious service attendance rates reported by the GSS (Smith, et al. 2012) of slightly over $25 \%$ for 30 -year olds. Even in comparison to the population of 30 -year old evangelical Christians, who attend services regularly at a rate of $41 \%$ according to the GSS, the regular church attendance rate reported in this study is nearly double that of similarly aged evangelicals.

Further analysis of church involvement revealed that over 59\% of survey respondents indicated involvement in formal church leadership positions. The most common positions were worship team members and Sunday school teachers.

Regarding denominational choices, over $47 \%$ of survey respondents indicated their continued attendance at the churches of the Mennonite denomination at the center of this study. About the same number (48\%) attended churches from a variety of other evangelical and Protestant denominations. Only 4.2\% indicated no affiliation with a church at all (see Table 2).

\section{Table 2: Church Denominational Affiliation}

\begin{tabular}{lcc} 
Type of Church Attended & $\mathrm{n}$ & $\%$ \\
\hline Conservative Mennonite Conference & 113 & 47.5 \\
Non-denominational & 42 & 17.6 \\
Non-CMC Mennonite/ Anabaptist & 35 & 14.7 \\
Other Protestant & 16 & 6.7 \\
Baptist & 15 & 6.3 \\
Vineyard/ Charismatic & 7 & 2.9 \\
Non-Christian/ No Church & 10 & 4.2 \\
Unknown & 2 & \\
\hline
\end{tabular}

Note. Percentages given are relative to $\mathrm{n}-2$. 


\section{Volunteerism}

Although the survey population studied seems to exceed the general population in religiosity, their involvement in volunteerism is more typical of the American populace. According to the GSS, 37\% of 30-year old Americans reported volunteering for a charitable or civic organization in a given year (Smith, et al. 2012). The NYSR reported a similar volunteerism rate (40\%) for emerging adults (Smith and Snell 2009). This compares to $45.8 \%$ of survey responses who reported the same thing.

\section{Interpretation and Analysis}

\section{Education and Regular Church Attendance}

In this study, regular church attendance was functionally defined as attendance at church services nearly every week or more. Cross tabulation and statistical analysis of the relationship between regular church attendance and the type of college attended revealed a number of significant findings.

The first statistically significant finding $(\mathrm{p}=.041)$ was that attendance at the denomination's Bible college was moderately correlated $(\phi=.132)$ to increased regular church attendance later in life. Specifically, $89.4 \%$ of those who attended the denomination's Bible college attended church regularly, compared to $75.6 \%$ for those who did not attend the college. Although the statistical relationship was too limited to be broadly conclusive, none of the other types of colleges analyzed yielded this high a percentage of regular church attendance (see Table 3).

\section{Table 3: RBC Attendance / Church Regularity Cross Tabulation}

\begin{tabular}{llcc|c}
\multicolumn{1}{c}{} & \multicolumn{3}{c}{ Church Regularity? } \\
\cline { 3 - 4 } & & Non-regular & Regular & Total \\
\hline \multirow{3}{*}{ RBC Attended } & Count & 5 & 42 & 47 \\
& Expected Count & 10.2 & 36.8 & 47.0 \\
& \% within RBC? & $10.6 \%$ & $89.4 \%$ & $100.0 \%$ \\
\hline \multirow{3}{*}{ RBC Not Attended } & Count & 47 & 146 & 193 \\
& Expected Count & 41.8 & 151.2 & 193.0 \\
& \% within RBC? & $24.4 \%$ & $75.6 \%$ & $100.0 \%$ \\
\hline \multirow{3}{*}{ Total } & Count & 52 & 188 & 240 \\
& Expected Count & 52.0 & 188.0 & 240.0 \\
& \% within RBC? & $21.7 \%$ & $78.3 \%$ & $100.0 \%$ \\
\hline
\end{tabular}

Note: $\chi^{2}=4.188, d f=1, p=.041, \phi=.132$ 


\section{Table 4: State University Attendance / Church Regularity Cross Tabulation}

\begin{tabular}{llcc|c}
\multicolumn{2}{c}{} & \multicolumn{2}{c}{ Church Regularity? } \\
\cline { 3 - 4 } & & Non-regular & Regular & Total \\
\hline \multirow{2}{*}{ State University } & Count & 19 & 31 & 50 \\
Attended & Expected Count & 10.8 & 39.2 & 50.0 \\
& \% within RBC? & $38.0 \%$ & $62.0 \%$ & $100.0 \%$ \\
\hline \multirow{2}{*}{ State University } & Count & 33 & 157 & 190 \\
Not Attended & Expected Count & 41.2 & 148.8 & 190.0 \\
& \% within RBC? & $17.4 \%$ & $82.6 \%$ & $100.0 \%$ \\
\hline \multirow{2}{*}{ Total } & Count & 52 & 188 & 240 \\
& Expected Count & 50.0 & 183.0 & 240.0 \\
& \% within RBC? & $21.7 \%$ & $78.3 \%$ & $100.0 \%$ \\
\hline
\end{tabular}

Note: $\chi 2=9.927, \mathrm{df}=1, \mathrm{p}=.002, \phi=.203$

A second statistically significant finding $(\mathrm{p}=.002)$ was the moderate relationship $(\phi=$ .203) between attendance at state universities and less regular church attendance later in life. Those who went to state universities attended church regularly $62.0 \%$ of the time, compared to a regular attendance rate of $83 \%$ for those not attending state college (see Table 4 ).

One final significant finding $(\mathrm{p}=.032)$ related to church attendance was that extracollegiate faith training experiences (i.e., discipleship training schools or short-term mission experiences) resulted in a moderately significant $(\phi=.138)$ correlation to greater regular church attendance later in life. Once again, while this relationship cannot be construed as causative, it does highlight the fact that, for this population, participation in a faith-based educational experience is indicative of the life choices of individuals who are more likely to be regularly involved in church as they enter adulthood.

\section{Education and church leadership}

Based on an examination of the data, and cross tabulation of the relationship between the various educational choices and church service, no statistical relationship was observed between college choice and church service. This lack of correlational relationship seems to indicate that, for this population, type of education is not a major consideration when churches and individuals consider involvement in leadership in the church setting.

\section{Education and civic volunteerism}

Cross tabulation and statistical analysis examined each of the educational types for correlation with regular civic volunteerism, operationally defined for this study as volunteering at least several times a year. For most college types examined, there was no statistically significant relationship between attendance at a particular type of college and civic volunteerism. 
Table 5: Rosedale Bible College Attendance / Regular Volunteerism Cross Tabulation

\begin{tabular}{llcc|c}
\multicolumn{2}{c}{} & \multicolumn{2}{c}{ Volunteer regularly? } \\
\cline { 3 - 4 } & & Non-regular & Regular & Total \\
\hline \multirow{3}{*}{ RBC Attended } & Count & 33 & 13 & 46 \\
& Expected Count & 26.8 & 19.2 & 46.0 \\
& \% within RBC? & $71.7 \%$ & $28.3 \%$ & $100.0 \%$ \\
\hline \multirow{3}{*}{ RBC Not Attended } & Count & 106 & 87 & 193 \\
& Expected Count & 112.2 & 80.8 & 193.0 \\
& \% within RBC? & $54.9 \%$ & $45.1 \%$ & $100.0 \%$ \\
\hline \multirow{3}{*}{ Total } & Count & 139 & 100 & 239 \\
& Expected Count & 139.0 & 100.0 & 239.0 \\
\hline
\end{tabular}

Note: $\chi^{2}=4.317, d f=1, p=.038, \phi=.134$

There was, however, one significant $(\mathrm{p}=.038)$ and surprising exception. Attendance at the denomination's Bible college was moderately related $(\phi=.134)$ to less regular civic volunteerism later in life. Survey respondents who attended the denomination's college volunteered regularly at a rate of only $28.3 \%$, compared to $45.1 \%$ for those who did not attend the denomination's college (see Table 5).

\section{Implications of Findings}

\section{Implications for the College's Mission}

The research at the center of this study was motivated by the understanding that accreditors and the public are increasingly interested in encouraging institutions of higher learning to use a mission-centric approach for outcomes assessment (ABHE 2007; Ewell 2008; U.S. Department of Education 2006). Behind this movement is the assumption that education, well executed, should have a measurable effect on the understandings and actions of students.

While the research results generated by a non-experimental study such as this one cannot be used to assert causation, they can point to correlations between educational choices and behavior that either support or contradict the possibility that the college is carrying out its mission, in this case by equipping students for service in the church and in society.

The three most significant research findings relative to the mission of the Bible college at the center of this study have been (a) the moderate relationship between attendance at the college and regular church attendance later in life, (b) the lack of statistically significant results related to the relationship between attendance at the college and church leadership later in life, and (c) the moderate relationship between attendance at the college and less regular civic volunteerism later in life. These three findings offer a mixed message regarding the likelihood that the college is 
carrying out its stated mission in full.

The first of these three correlations supports the possibility that the college is succeeding in its mission of equipping students for service in the church, at least as far as commitment to regular church attendance is concerned. Thus, the college leadership can take comfort in the finding that attendance at the college is an indicator of the increased probability of regular church attendance later in life.

The second finding offers no evidence one way or another regarding the possibility that the college is preparing students for service in the church. One of the implications from this finding is that there is no apparent special relationship between the churches of the denomination and the denomination's college when it comes to involving former students in church leadership positions to any greater degree than students from other educational settings. The college, which promotes itself as the denomination's place of preparation for church service, might do well to proactively partner with the churches of the denomination to promote a greater placement of its graduates in positions of church leadership.

The third finding - that attendance at the denomination's college correlates with less regular civic volunteerism-raises serious questions about whether the college has adequately equipped students for service in society. This finding is particularly troubling given the overt commitment to service that is foundational to the Bible college ethos (ABHE 2012; McKinney 1997). The prime implication of this last finding is that the college would do well to evaluate more fully the effectiveness of its teaching program relative to expressing ideals that value civic volunteerism.

When taken together, one of the main possibilities that these research findings point to is that while the college may be effective at developing faithful, but inwardly (church) focused Christians, what is needed according to the college's stated mission, is the development of faithful, outwardly (community) focused Christians.

\section{Implications for Academic Research}

The research related to this article was significantly informed by other studies. Furthermore, the findings from this study have implications that either confirm or raise questions about related research. Perhaps most significantly, the findings from this research seem to support other research that has found a relationship between Christian education experiences and increased religiosity later in life (Dudley 1999; Henderson 2003). Conversely, for this survey population, the findings from this research raise questions about the universal applicability of research that points toward increasing or sustained levels of religiosity as an outcome of a public higher education experience (Arnett and Jensen 2002; Pascarella and Terenzini 2005; Uecker, et al. 2007). This study found the opposite; that attendance at secular educational institutions was related to lower levels of regular attendance at church later in life. 


\section{Limitations}

It must first be recognized that the data from this study are primarily demographic and correlational in nature. This means that while this information may inform the college's leadership and its sponsoring denomination of the choices of the denomination's young people, it is not possible to infer direct causation from this information alone. In a similar sense, since programs, curricula, cultures, and environments differ at other colleges, it would not be advisable to use these data to infer broad conclusions about the educational programs and outcomes at other colleges, even if they are similarly constituted Bible colleges.

There are also some limitations related to the study population, which represents a subset of the whole. Because of this, it is likely that factors beyond the control of the researcher may have skewed the final makeup of the population somewhat, compromising the extent to which it was representative of the overall population. For example the response rate for females was quite a bit higher than the response rate for males. In addition, students who had attended the denomination's Bible College were overrepresented due to a higher response rate from that particular cohort. These factors add a level of uncertainty to the representative nature of the data received from this survey. Nevertheless, the relatively robust response rate lends credence to the validity of the study's findings.

\section{Recommendations for Future Research}

There is currently a limited amount of research studying the link between post-secondary education, particularly religious education, and later religiosity and volunteerism. One of the additional research areas that might be helpful would be follow-up research related to this particular study. Specifically, a survey in five years, given to the same cohort, may reveal longitudinal information about the trajectory of this group of individuals, particularly regarding their continued engagement in church and service involvement. Another consideration would be to administer this same survey in 2019 to the next cohort of emerging adults from the sponsoring denomination (high school graduation years 2005 to 2010). This type of study would provide the chance for the college and denomination to compare cohorts for changes that might be occurring as a result of the sociological or religious context of survey participants. In addition, the college would then be able to use the data to help evaluate some of the curricular changes that came about as a result of a major institutional vision initiative in 2006 that identified community “engagement” an important institutional value (Ziegler 2006).

Finally, beyond the scope of this research, there is a question whether the correlation between attendance at the denomination's Bible College and less regular volunteerism is an isolated phenomenon, or whether this situation is common within the Bible college context in general. Similar research across other Bible college settings may help answer this question. 


\section{Endnote}

${ }^{1}$ Dan Ziegler is currently serving as administrator of a conservative Anabaptist NGO in Haiti. Prior to that he served eight years as President of Rosedale Bible College, where he taught courses in leadership and marketing. He has earned an Ed.D. in organizational leadership from Nova Southeastern University and an M.S. in Management from Thomas Edison State College. Dan can be reached at Unit 2096 BRIC, 3170 Airmans Dr., Ft. Pierce, FL 34946 or at brotherziegler@gmail.com

\section{References}

Anderson, Cory. 2013. "Who Are the Plain Anabaptists? What Are the Plain Anabaptists?” Journal of Amish and Plain Anabaptist Studies 1(1):26-71.

Arnett, Jeffery. 2000. "A Theory of Development from the Late Teens through the Twenties." American Psychologist 55:469-80.

Arnett, Jeffery, and Lene Jensen. 2002. "A Congregation of One: Individualized Religious Beliefs among People in Their Twenties.” Journal of Adolescent Research 17:451-67.

Association for Biblical Higher Education. 2007. Accreditation Action Response: Rosedale Bible College. Orlando, FL: Association for Biblical Higher Education.

Association for Biblical Higher Education. 2012. “ABHE Facts.” Association for Biblical Higher Education. Retrieved August 21, 2012 (abhe.org/pages/NAVABHEFacts.html).

Barna, George. 2001. Real Teens: A Contemporary Snapshot of Youth Culture. Ventura, CA: Regal Press.

Barna, George. 2006. "Most Twentysomethings Put Christianity on the Shelf Following Spiritually Active Teen Years.” Retrieved September 2, 2012 (www.barna.org/barnaupdate/article/16-teensnext-gen/147-most-twentysomethings-put-christianity-on-theshelf-following-spiritually-active-teen-years).

Barry, Carolyn, Larry Nelson, Sahar Davarya, and Shirene Urry. 2010. "Religiosity and Spirituality during the Transition to Adulthood.” International Journal of Behavioral Development 34:311-24.

Brenner, Philip. 2011. "Identity Importance and the Overreporting of Religious Service Attendance: Multiple Imputation of Religious Attendance Using the American Time Use Study and the General Social Survey.” Journal for the Scientific Study of Religion 50(1):103-15. 
Brooks, Arthur. 2006. Who Really Cares: America's Charity Divide. New York, NY: Basic Books.

Conservative Mennonite Conference. 2011. Conservative Mennonite Conference Annual Report 2011. Irwin, OH: Conservative Mennonite Conference.

Dudley, Roger. 1999. "Youth Religious Commitment over Time: A Longitudinal Study of Retention.” Review of Religious Research 41(1):110-21.

Ewell, Peter. 2008. U.S. Accreditation and the Future of Quality Assurance: A Tenth Anniversary Report from the Council for Higher Education Accreditation. Washington, DC: The Council for Higher Education Accreditation.

Fink, Arlene. 2003. How to Manage, Analyze, and Interpret Survey Data (second edition). Thousand Oaks, CA: Sage Publications.

Funk, Richard, and Fern Willits. 1987. "College Attendance and Attitude Change: A Panel Study, 1970-81.” Sociology of Education 60:224-31.

General Social Survey. n.d. About the GSS. Retrieved September 13, 2012 (www3.norc.org/ GSS+Website/About+GSS).

George, Darren, and Paul Mallery. 2006. SPSS for Windows Step by Step: A Simple Guide and Reference $6^{\text {th }}$ ed.]. Boston, MA: Pearson Education, Inc.

Gibson, Troy. 2008. "Religion and Civic Engagement among America’s Youth.” The Social Science Journal 45:504-14.

Gingerich, Melvin. 1953. "Mennonite Colleges and Universities.” Global Anabaptist Mennonite Encyclopedia Online. Retrieved August 23, 2011 (gameo.org/encyclopedia/ contents/colleges_and_universities_mennonite)

Greely, Andrew. 1997. “The Other Civic America: Religion and Social Capital.” The America Prospect 32:68-74.

Gunnoe, Marjorie, and Kristin Moore. 2002. "Predictors of Religiosity among Youth Aged 1722: A Longitudinal Study of the National Survey of Children.” Journal for the Scientific Study of Religion 41(4):613-22.

Hadaway, C. Kirk, and Penny Marler. 2005. "How Many Americans Attend Worship Each Week? An Alternate Approach to Measurement.” Journal for the Scientific Study of Religion, 44(3):307-22. 
Hadaway, C. Kirk, Penny L. Marler, and Mark Chaves. 1998. "Over-Reporting Church Attendance in America: Evidence That Demands the Same Verdict.” American Sociological Review 63:122-30.

Hadaway, C. Kirk and Wade Roof. 1988. "Apostasy in American churches: Evidence from National Survey Data.” Pp. 29-46 in Falling from the Faith: Causes and Consequences of Religious Apostasy, edited by David Bromley. Thousand Oaks, CA: Sage Publications.

Healy, Joseph. 2010. The Essentials of Statistics: A Tool for Social Research (second edition). Belmont, CA: Wadsworth Cengage Learning.

Heckman, James, and Paul LaFontaine. 2010. "The American High School Graduation Rate: Trends and Levels.” Review of Economics and Statistics 92(2):244-62.

Henderson, Steven. 2003. The Impact of Student Religion and College Affiliation on Student Religiosity. Retrieved February 13, 2011 (www.christianconsulting.net/statistics/ Dissertation.pdf).

Hill, Jonathan, and Kevin den Dulk. 2013. "Religion, Volunteering and Educational Setting: The Effect of Youth Schooling Type on Civic Engagement.” Journal for the Scientific Study of Religion. 52(1):179-97.

Hunter, James. 1983. American Evangelicalism, Conservative Religion, and the Quandary of Modernity. New Brunswick, NJ: Rutgers University Press.

Kinnaman, David, and Gabe Lyons. 2007. Un-Christian: What a New Generation Really Thinks about Christianity...And Why It Matters. Grand Rapids, MI: Baker Books.

Kraybill, Donald. 2010. Concise Encyclopedia of Amish, Brethren, Hutterites, and Mennonites. Baltimore, MD: Johns Hopkins University Press.

Lederach, Paul, and Harold Bender. 1959. "Winter Bible Schools.” Global Anabaptist Mennonite Encyclopedia. Retrieved August 16, 2011 (www.gameo.org/encyclopedia/ contents/winter_bible_schools).

Lee, Gary, Alfred DeMaris, Stefoni Bavin, and Rachel Sullivan. 2001. "Gender Differences in the Depressive Effect of Widowhood in Later Life.” Journals of Gerontology, Series B: Psychological Sciences and Social Sciences 56:56-61.

Lee, Jenny. 2002. "Religion and College Attendance: Change among Students” Review of Higher Education 25(4):369-84.

McKinney, Lawrence. 1997. Equipping for Service. Fayetteville, AR: Accrediting Association of Bible Colleges. 
Musick, Mark, and John Wilson. 2008. Volunteers: A Social Profile. Indianapolis, IN: Indiana University Press.

O’Connor, Thomas, Dean Hoge, and Estrelda Alexander. 2002. “The Relative Influence of Youth and Adult Experiences on Personal Spirituality and Church Involvement.” Journal for the Scientific Study of Religion 41(4):723-32.

Ozorak, Elizabeth. 2003. "Love of God and Neighbor: Religion and Volunteer Service among College Students.” Review of Religious Research 44:285-99.

Pascarella, Ernest, and Patrick Terenzini. 2005. How College Affects Students: A Third Decade of Research (Vol. 2). San Francisco, CA: Jossey-Bass.

Pew Research Center. 2010. Millennials: A Portrait of Generation Next. Retrieved September 3, 2011 (www.pewsocialtrends.org/files/2010/10/millennials-confident-connectedopen-to-change.pdf).

Princeton Religion Research Center. 2002. "Many Say Religion Is Increasing Influence, but Churchgoing Flat.” Emerging Trends 24(1):1-2.

Rosedale Bible College. 2011. Rosedale Bible College Catalog 2011-2012. Irwin, OH.

Smith, Christian, Kari Christoffersen, Hillary Davidson, and Patricia Snell Herzog. 2011. Lost in Transition: The Dark Side of Emerging Adulthood. New York, NY: Oxford University Press.

Smith, Christian, and Melinda Denton. 2005. Soul Searching: The Religious and Spiritual Lives of American Teenagers. New York, NY: Oxford University Press.

Smith, Christian, and Patricia Snell. 2009. Souls in Transition: The Religious and Spiritual Lives of Emerging Adults. New York, NY: Oxford University Press.

Smith, Tom, Peter Marsden, Michael Hout, and Jibum Kim. 2012. "General Social Surveys, 1972-2010: Cumulative Codebook.” National Data Program for the Social Sciences Series, 21. Chicago, IL: National Opinion Research Center.

Speck, Bruce. 2005. “What Is Spirituality? Spirituality in Higher Education.” Pp. 3-13 in New Directions for Teachers and Learning, edited by Sherry Hoppe and Bruce Speck. San Francisco, CA: Jossey-Bass.

Stoppa, Tara, and Eva Lefkowitz. 2010. "Longitudinal Changes in Religiosity among Emerging Adult College Students.” Journal of Research on Adolescence 20(1):23-28.

U.S. Bureau of Labor Statistics. 2008. Volunteering in the United States. Washington, D.C.: U.S. Government Printing Office. 
U.S. Department of Education. 2006. A Test of Leadership: Charting the Future of U.S. Higher Education. Washington, D.C.: U.S. Government Printing Office

U.S. Department of Education. 2010. Trends in the Use of School Choice: 1993 to 2007. Washington, D.C. Retrieved June 14, 2011 (nces.ed.gov/pubs2010/2010004.pdf).

U.S. Department of Education, National Center for Education Statistics. 2011. "Table 213: Enrollment Rates of 18- to 24-Year-Olds in Degree-Granting Institutions, by Level of Institution and Sex and Race/Ethnicity of Student: 1967 through 2010.” In Digest of Education Statistics. Retrieved August 24, 2012 (nces.ed.gov/programs/digest/d11/ tables/dt11_213.asp)

Uecker, Jeremy, Mark Regnerus, and Margaret Vaaler. 2007. "Losing my Religions: The Social Sources of Religious Decline in Early Adulthood.” Social Forces 85(3):1667-92.

Wenger, John C. 1977. What Mennonites Believe. Scottdale, PA: Herald Press.

Yoder, Elmer, and Jewel Showalter. 1992. We Beheld His Glory: Rosedale Bible Institute, the First Forty Years. Irwin, OH: Rosedale Bible Institute.

Yoder, Nathan. 2014. Together in the Work of the Lord. Harrisonburg, VA: Herald Press

Ziegler, Daniel. 2006. Rosedale Bible College Annual President's Report. Irwin, OH: Rosedale Bible College.

Ziegler, Daniel. 2011. Rosedale Bible College Annual President's Report. Irwin, OH: Rosedale Bible College. 